\title{
Who Beats Plowshares into Swords? Determinants of Commitment to Ceasefire Agreements
}

\author{
Junghyun Lim and Geunwook Lee
}

\begin{abstract}
Although ceasefire agreements end wars, they are not left unthreatened. A number of ceasefire agreements have been threatened or violated in various ways. A ceasefire agreement collapses when at least one adversary fails to comply with the agreement it previously accepted and resumes military conflict against its old enemy. Why do some states break ceasefire agreements while others carry them out? Under what conditions are states less likely to commit to ceasefire agreements? Previous studies on the commitment problem identify regime type, relative capability, and power shift as important variables that affect the ability of states to commit to agreements. Accordingly, this paper examines whether those variables have a significant effect on states' commitment to ceasefire agreements.

To test the effects of those variables, I build a data set using MIDB, COW, NMC, and Polity IV data. To test the effects of those variables, a dataset was constructed using MIDB, COW, NMC, and Polity IV data. A key finding of this paper is that democracies are no more likely to commit to agreements than nondemocracies, while relative power and power shifts have statistically significant effects on commitment to agreements. This paper suggests that democratic advantage on commitment does not exist, at least with regard to ceasefire agreements.
\end{abstract}

Key Words: ceasefire agreement, commitment problem, democratic advantage, relative capability, power shift

easefire agreements end wars but are not left unthreatened. A number of agreements have been violated or threatened in various ways. Some states take military action or even attempt to resume wars against old enemies despite previously-approved ceasefire agreements. Why, then, do some states break agreements while others carry them out? Under what conditions are states more likely to beat plowshares back into swords?

*Junghyun Lim (primary author, goonijung@gmail.com) is a graduate student (MA program) in the Department of Political Science, Sogang University. She presented an earlier version of this paper at the MPSA (Midwest Political Science Association) Conference in Chicago, IL (USA), in April 2015.

**Geunwook Lee (secondary author, glee@sogang.ac.kr) is a professor in the Department of Political Science, Sogang University. He teaches international relations and security affairs.

An earlier version of this paper was presented at the MPSA Conference (Chicago, USA) in April 2015. The primary author of this paper (Junghyun Lim) was the presenter.

The Korean J ournal of International Studies Vol.13-3 (December 2015), 489-512.

http://dx.doi.org/10.14731/kjis.2015.12.13.3.489

(c) 2015 The Korean Association of International Studies 
Previous studies mostly concentrate on the durability of peace after a given ceasefire, seeking to find favorable conditions for lasting peace and durable ceasefire agreements (Bennett 1998; Werner 1999; Fortna 2004). Most prominently, Fortna (2004) examined the effect of the content of a ceasefire agreement on the durability of peace following the agreement. However, one problem remained unaddressed: variation in the behavior of states regarding their commitment to ceasefire agreements.

A ceasefire agreement collapses when at least one of the adversaries fails to honor the agreement it previously had accepted. However, previous studies do not distinguish among the behaviors of states regarding ceasefires and thus fail to explain variation in states' commitment to agreements. Instead, those studies tended to concentrate on the durability of agreements. Grieco (2001) is an important exception. His study found that a range of national conditions affect the risk of the resumption of conflict. However, this mainly focuses on repetitive military challenges made by the same parties without concern for whether an agreement exists. This paper, on the other hand, concentrates on cases where ceasefire agreements are violated and seeks to identify the conditions in which states are more likely to fail to uphold agreements.

This paper explores the issue as a commitment problem. Under what conditions are states more likely to fail in their commitment to an agreement? Why do they beat plowshares back into swords rather than commit to peace? By identifying the collapse of a ceasefire as a commitment problem and exploring what makes states better commit to an agreement, this paper aims to concentrate on the behavior of each state, rather than of each dyad, and address variation in state commitment.

Regarding the commitment problem, two important variables emerge: regime type and relative power. Regime type is considered important because the states' ability to commit to an agreement may vary depending on regime type (Martin 2000; McGillivray and Smith 2000; Leeds, Mattes, and Vogel 2009). More specifically, democracies are expected to commit more than nondemocracies because of their institutional advantages. On the other hand, power distributions and power shifts may cause states to reverse previously-made decisions and fail to commit themselves to agreements. For instance, when there is a shift in the distribution of power, states may fail to commit to agreements because the conditions upon which the agreements were premised have changed (Van Evera 1999). In addition to these variables, there are others that might affect state behavior regarding ceasefire agreements, including the outcomes or costs of previous wars. This paper seeks to find what determines a state's ability to commit to a ceasefire agreement by examining the effects of the above mentioned variables. In 
order to test the effect of each variable on state commitment, a dataset was constructed using Militarized Interstate Disputes B (MIDB), Correlation of War (COW), National Material Capabilities (NMC), and Polity IV data. Based on a list of ceasefire agreements signed from 1945 to 1997 (Fortna 2004), this dataset covers all cases in which ceasefire agreements were violated. ${ }^{1}$ Using this dataset, this paper aims to find the determinants of states' commitment to interstate agreements.

The first section of this paper reviews general theories of commitment, focusing on the effects of democracy, relative capabilities, and changes in relative capabilities. The second section proposes the hypotheses to be examined, based on general theories of commitment, including theories about democratic advantages and relative capabilities. The third section presents the methodology and data used in this paper. The fourth reports the empirical findings, and finally, the concluding section points out the limitations of the paper and offers several suggestions for further research.

\section{COMMITMENT THEORIES}

Exploring the question of why states break ceasefire agreements is closely related to the causes of conflict because, when a ceasefire is broken, it means that one of the parties has taken renewed military action against its old enemy. However, unlike other studies on the causes of conflict, this paper only considers cases where military conflicts are resumed despite the existence of a ceasefire agreement. Hence, this paper focuses on the commitment to ceasefire agreements rather than analyzing all military conflicts among nations.

There are several theoretical explanations for the commitment problem in the field of international relations (IR), including the effect of multilateral cooperation, geographic contiguity, and so forth. However, since this paper focuses on variations in state behavior regarding commitment to agreements, theories that focus on variables affecting both states in the same manner are excluded. In this sense, there are two categories of theories emphasizing different independent variables: regime type and distribution of power.

\footnotetext{
${ }^{1}$ Besides the list by Fortna, there is the UCDP Peace Agreement Dataset which covers more recent cases. Although the UCDP dataset provides a list of more recent agreements, for this paper, Fortna's list seems to be more appropriate since the UCDP dataset covers agreements that end all sorts of armed conflicts, including civil wars, whereas this paper focuses only on agreements that end interstate wars. In the Data and Methodology section, differences between the two datasets and the reasons why only Fortna's list is used are described more specifically.
} 


\section{DEMOCRACY AND COMMITMENT}

The effect of regime type on interstate commitment has been discussed frequently in previous studies. While all of those studies explore whether regime type affects state behavior in foreign policy, they show contrasting results.

Some studies show that institutional characteristics or restraints encourage democracies to comply with international agreements. Martin (2000) argues that democracies commit to international agreements more than nondemocracies thanks to legislative participation. Focusing on democratic leaders, McGillivray and Smith (2000) argue that such leaders are less likely to violate international agreements because they fear punishment from their domestic audiences. Likewise, Leeds, Mattes, and Vogel (2009) contend that policy consistency, which is directly related to compliance with long-term agreements, is more frequently observed in democracies than nondemocracies. They stress that the regular turnover of leadership in democracies does not make states less able to commit to agreements. Although these studies differ in terms of the mechanisms they posit as underlying the superior capacity of democracies to commit to agreements, they commonly argue that the institutions of democracies, which are distinct from those of nondemocracies, make democracies comply with agreements more frequently.

On the other hand, other studies present counterarguments that cast doubt on the persistence of democracies to comply with international agreements compared to nondemocracies. Gartzke and Gleditsch (2004) examine the effect of regime type on the durability of alliances and argue that democracies are less likely to remain committed. In addition, several studies contend that democracies are less likely to comply with certain international trade agreements (Simmons 2000). These studies argue that democratic institutions are rather less favorable to long-term commitments.

Such contradictory findings indicate there is still room for debate about the effect of democratic institutions on commitment. One possible explanation for the conflicting results is that effects can vary depending on the issue area; another is that each study focuses on different features of democratic institutions. This paper does not aim to explain which features of democratic institutions actually determine a state's commitment to ceasefire agreements. Instead, this paper attempts to identify whether the commitment mechanisms of democracies work better than those of nondemocracies with regard to ceasefire agreements. 


\section{RELATIVE POWER AND COMMITMENT: STATICS AND DYNAMICS}

Distribution of power is one of the most commonly used variables in the field of international relations. The effect of this variable is examined in two different ways: statically and dynamically.

First, a number of international scholars tend to examine the effect of the distribution of power statically. Generally, distribution of power is expected to affect the stability of international environments and state behavior. Here, the issue is under which type of power distribution states resume conflicts and make commitments unreliable.

At the systemic level, whether a preponderance of power or a balance of power contributes to maintaining stability is debatable. At the unit level, on the other hand, whether a superior power is more likely to initiate conflict is a more relevant question. Since this paper seeks to find the determinants that affect the behavior of individual states, the focus will be on which power in a rivalry is more likely to fail to honor its commitment and resume conflict: the superior power or the inferior power.

Second, the effect of the distribution of power also has been examined in terms of dynamic change. Power transition is considered an important variable affecting state behavior in terms of military action and commitment in general. The idea of power shifts has been discussed since Thucydides proposed that the Spartans attacked Athens for fear that Athenian capabilities might grow further and eventually allow the Athenians to overwhelm Sparta. This implies that states may reverse their tendencies when the distribution of power shifts. Therefore, fluctuations in relative power are expected to cause states to fail to honor agreements by changing the conditions upon which the agreements were premised (Van Evera 1999). A fluctuation in relative power means that one of the adversaries rises in terms of capabilities while the other declines. When the distribution of power changes, states may modify their ideas about previously-signed agreements.

When there is an increase in power, a state might be inclined to break an agreement that was premised on that state being the weaker party. However, the declining power also notices this impending result of power shifts. Powell (2012) points out the trade-off that states face in this situation: when the distribution of power shifts, declining states should make choices between bearing the cost of fighting and running the risk of defeat or avoiding these immediate costs at the price of being in a much weaker position in the future. Declining states may bear the cost of fighting and conduct military action in order to slow or stop any fur- 
ther shifts in relative power, but they might also avoid immediate conflict if the cost of fighting is too large to bear. This implies that a power shift may change a state's incentive to commit to a previously-accepted agreement.

The theory of power shifts can be applied to states' compliance with ceasefire agreements. By focusing on the individual state as the unit of analysis, this paper examines the effect of power shifts on state behavior. In other words, this paper explores the choices declining powers make when facing the dilemma of a shift in relative power. This differs from previous studies that have focused on whether fluctuations in the distribution of power led to a breakdown of agreements.

\section{HYPOTHESES}

In order to identify the determinants of states' commitment to ceasefire agreements, several hypotheses are proposed based on the general theories of commitment described above. Seven hypotheses are presented below. As Table 1 shows, hypotheses (a), (b), (c), and (c-1) are intended to assess the validity of the commitment theories reviewed in the previous section. Each hypothesis examines the effects of democracy, relative power, and power transition, as shown below.

Table 1. Commitment Theories and Hypotheses to be Examined

\begin{tabular}{|c|c|c|}
\hline \multicolumn{2}{|c|}{ Theoretical perspectives on commitment } & Hypotheses \\
\hline \multicolumn{2}{|c|}{$\begin{array}{l}\text { 1. Democracy and commitment to } \\
\text { an agreement }\end{array}$} & $\begin{array}{l}\text { Hypothesis (a): } \\
\text { Democracies are more likely to observe ceasefire } \\
\text { agreements than nondemocracies. }\end{array}$ \\
\hline \multirow[b]{2}{*}{$\begin{array}{l}\text { 2. Power distribution and } \\
\text { commitment to } \\
\text { an agreement }\end{array}$} & $\begin{array}{l}\text { 2-1 } \\
\text { Relative power }\end{array}$ & $\begin{array}{l}\text { Hypothesis }(b) \text { : } \\
\text { A state with superior capabilities is more likely to } \\
\text { violate a ceasefire agreement. }\end{array}$ \\
\hline & $\begin{array}{c}2-2 \\
\text { Power shift }\end{array}$ & $\begin{array}{l}\text { Hypothesis (c): } \\
\text { A state that has grown in relative capabilities since a } \\
\text { ceasefire agreement was signed is more likely to } \\
\text { violate the agreement. } \\
\text { Hypothesis (c-1): } \\
\text { A state that has declined in relative capabilities since a } \\
\text { ceasefire agreement was signed is more likely to vio- } \\
\text { late the agreement. }\end{array}$ \\
\hline
\end{tabular}

Hypothesis (a): Democracies are more likely to observe ceasefire agreements than nondemocracies. 


\section{Hypothesis (a-1): The level of democracy affects state behavior. States that are more democratic are more likely to respect ceasefire agreements.}

Hypotheses (a) and (a-1) are intended to assess whether regime type and level of democracy affect state behavior in terms of commitment to ceasefire agreements. As noted in the previous section, some argue that because of their institutional restraints, democracies are more likely to commit to agreements than nondemocracies. Following this argument, democratic states should be less likely to violate ceasefire agreements than nondemocracies. However, there are counterarguments contending that democracies are less likely to remain committed because of regular leadership replacement. In addition, it is questionable whether institutional restraints are effective in maintaining commitments, even against old enemies. Although Bennett (1998) argues that domestic factors, including regime type, affect the termination of enduring rivalries, they do not sufficiently explain whether democratic states observe agreements better than nondemocracies. This is because Bennett focuses on each rivalry and only distinguishes rivalries between democracies and nondemocracies from rivalries between nondemocracies.

In order to assess the effect of regime type, Hypothesis (a) posits that democracies are more likely to respect agreements. However, Hypothesis (a) is only applicable to cases involving disputes between democracies and nondemocracies since regime type only describes whether a state is democratic or not. Therefore, Hypothesis (a-1) is used to examine whether a higher level of democracy makes a state more likely to observe an agreement. This hypothesis covers all cases in which a ceasefire is broken; this may help to make the result of Hypothesis (a) more robust since Hypothesis (a-1) is able to assess the entire case.

Hypothesis (b): A state with superior capability is more likely to violate a ceasefire agreement.

Hypothesis (b) is proposed to examine the effect of the distribution of power on compliance with ceasefire agreements. Generally, relative power is a variable that is expected to affect state behavior and the stability of the international environment. By testing Hypothesis (b), it is possible to tell whether relative capabilities have a significant effect on state behavior with regard to commitment to ceasefire agreements. In addition, it may show under which condition of relative power states are more likely to commit to ceasefire agreements and not take military action first. 


\section{Hypothesis (c): A state that has grown in relative capabilities since a ceasefire agreement was signed is more likely to vio- late the agreement.}

\section{Hypothesis (c-1): A state that has declined in relative capabilities since a ceasefire agreement was signed is more likely to violate the agreement.}

While Hypothesis (b) focuses on the distribution of power in a static state, Hypotheses (c) and (c-1) are proposed to examine the effect of the distribution of power in a dynamic situation involving power shifts. The two hypotheses are examined in order to find out whether power shifts affect the violation of ceasefire agreements. Additionally, the two hypotheses are conflicting; Hypothesis (c) suggests that a rising power is more likely to violate the agreement first, while Hypothesis (c-1) suggests that a declining power is more likely to violate the agreement, which is consistent with the logic of preventive war. ${ }^{2}$

Werner (1999) contends that a state's decision to restart a dispute is part of an ongoing bargaining process; thus, changes in relative capabilities do affect the durability of peace. Though this shows the importance of changes in relative capabilities, the mere fact that changes in relative capabilities affect the durability of peace does not show how those changes influence state behavior. More specifically, this does not show whether a state that grows in relative capabilities is more likely to resume conflict than a state that declines in relative capabilities is more likely to resume it to prevent becoming further disadvantaged relative to its rival(i.e. preventive war). Testing the rival Hypotheses (c) and (c-1) may help unravel this puzzle and identify whether a declining power or a rising power is more likely to violate a ceasefire agreement first.

In addition, there are other hypotheses tested with regard to residual issues.

\section{Hypothesis (d): The higher the cost a state spent in the last war, the less likely it is to violate an agreement.}

While Hypotheses (a) and (b) focus on the condition a state is in when it resumes military conflict, Hypothesis (d) assumes that the situation at the time of the ceasefire agreement influences state behavior. The higher was the cost of a previous war, the more reluctant a state would be to restart conflict since it might entail another expensive war. Some previous studies, including significant work by Fortna (2004), use the costs of war as a control variable that may influence the

\footnotetext{
${ }^{2}$ The authors would like to thank an anonymous reviewer for this criticism.
} 
durability of peace.

Hypothesis (e): The state on the losing side is more likely to resume military conflict.

The outcome of a war has been considered an important factor determining whether conflict recurs. Previous studies focused on pairs of states when analyzing recurrent conflicts. Examining the reasons why some rivalries endure while others terminate in the short-term, Stinnett and Diehl (2001) showed that wars that end in stalemate differ from wars that end with a decisive victory or defeat for one side. Hypothesis (e) is intended to clarify the effect of each war's outcome.

This paper aims to identify whether there is any difference with regard to the violation of ceasefire agreements in cases where a previous war ended in stalemate or in a decisive victory/defeat. Accepting that these two cases differ with regard to the likelihood of recurrence, it is also possible to question whether the factors affecting state behavior (to violate or not) are the same in both cases (wars ending in stalemate compared to wars ending with a decisive outcome). If it is true that a state is less likely to violate an agreement when a previous war ended with a decisive outcome, states that resume war in such cases may differ from those that experienced stalemate. Based on this idea, in the third part of the empirical findings, the entire dataset is divided into two groups depending on the outcome of war, and the effects of the independent variables on the dependent variable are examined separately.

\section{DATA AND METHODOLOGY}

This paper examines the commitment to ceasefire agreements; why some states break agreements by taking military action first. To explore this question, cases in which ceasefire agreements were violated are examined. A dataset is constructed based on a list provided by Fortna of ceasefire agreements signed between 1946 and 1997. Besides Fortna's list, there is the UCDP Peace Agreement Dataset, which covers peace agreements signed between 1975 and 2011. This dataset provides a list of peace agreements followed by various kinds of armed conflicts, including civil war. However, because this paper aims to identify the determinants of commitment at the state level, it restricts its focus to ceasefire agreements that end interstate war. In addition, in the UCDP data, armed conflict is defined as a conflict which results in more than 25 battle-related deaths; however, this paper focuses on interstate wars resulting in more than 1,00o bat- 
tle-related deaths. For this paper, therefore, the dataset was constructed based on Fortna's list, which reports ceasefire agreements followed by interstate wars, although it should be noted that the list is dated. ${ }^{3}$

The list includes forty-eight cases, and each involves a ceasefire between two major states that engaged in warfare. ${ }^{4}$ Each agreement was classified based on whether it had been observed or violated from the time it was signed up through 2007. In this paper, violation of a ceasefire agreement is defined as an attempt to resume a military dispute between two states. Agreements were considered violated based on the variable "HostLev," which is a hostility indicator in the MIDB dataset. This variable ranges from one to five, where a hostility level greater than three ("display of force") is considered to be a violation of an agreement. Cases with scores below three are not considered violations because they do not involve states taking direct action. Score one and two report "no military action" and "threat to use force," respectively. Three indicates a "display of force," four indicates "use of force," and five indicates "war." All cases reporting hostility levels greater than three from 1946 to 2007 are included in the dataset of this paper.

\section{DEPENDENT VARIABLE}

A binary variable, "violator," is used as the dependent variable in this paper. A state is coded as 1 if it violates a given ceasefire agreement and takes military action preemptively against its old enemy despite the agreement; otherwise, the state is coded as o. This variable combines two indicators from the MIDB data: "SideA" and "Orig." The SideA variable indicates states that are the first movers in the military dispute. However, the SideA indicator alone cannot distinguish which state first takes military action against the other state in a dyad because it marks all states that are on the same side with the first mover in the overall dispute. Therefore, the indicator Orig is used to resolve this problem. The Orig variable from the MIDB dataset shows whether a state was involved in the first stage of a dispute. Orig is coded as 1 if a state was directly involved in the first stage; otherwise, it is coded as o. Only cases in which Orig is coded as 1 (i.e., a state is

\footnotetext{
${ }^{3}$ The authors would like to thank an anonymous reviewer for this criticism.

${ }^{4}$ In the UCDP Peace Agreements Dataset, the number of peace agreements between 1998 and 2011 not included in the data used in this paper is more than 80. Among these agreements, however, the number of agreements that ended interstate wars resulting in more than 1,00o battle-related deaths was one: the Agreement between the Government of the State of Eritrea and the Government of the Federal Democratic Republic of Ethiopia (2000), which attempted to end the Badme Border War.
} 
directly involved in resuming a conflict that breaks a ceasefire agreement) are used in this paper.

\section{INDEPENDENT VARIABLES}

The "regime type" variable is based on Polity IV data. The "Polity" variable in the Polity IV dataset uses a 20-point scale ranging from negative 10 (strongly authoritative) to positive 10 (strongly democratic). Conventionally, states with scores greater than positive 6 are identified as democratic states, while those scoring positive 5 or less are considered nondemocratic. ${ }^{5}$ Following this convention, the regime type variable categorizes states into two groups: democratic states and nondemocratic states coded as 1 and o, respectively. To assess "level of democracy," I use the "Polity" variable without any categorization.

The Composite Index of National Capabilities (CINC) score from NMC data is used to measure "relative capabilities." CINC, which reports the capabilities of each state, uses an average of six indicators that represent demographic, industrial, and military dimensions. For each state in each dyad, the CINC score is divided by the sum of the CINC scores of both states in the dyad. Another variable, "change in relative capabilities," shows how the balance of capabilities between the two states in a dyad changed from the time the ceasefire agreement was signed to when the dispute resumed. For this variable, the value of relative capabilities when a dispute recurs is divided by the value of relative capabilities when the ceasefire agreement was signed. This shows how many times relative capabilities has changed from agreement to violation.

Following convention, the "cost of war" variable is measured by battle deaths in the previous war that ended with a ceasefire agreement. This is taken from the COW dataset. In order to distinguish the war outcome at the state level, the "outcome" indicator from the COW dataset is used. Two dummy variables are used to assess whether the war outcome had an effect on violation: the war ended in a stalemate or the war ended in a decisive victory or defeat for one side. For the first dummy variable, a value of 1 is given if the state won the war; otherwise, $o$ is assigned ("winner/loser or stalemate"). For the second dummy variable, a value of 1 is given if the war ended in stalemate, while $\mathrm{o}$ is assigned otherwise ("stale-

\footnotetext{
${ }^{5}$ In the Polity IV data, "democracy" is conceived broadly in terms of three elements: the existence of institutions through which civilians can express their preferences regarding policy and leaders, the presence of institutionalized constraints on executive power and, lastly, the guarantee of civil liberties. For more information, see "Polity IV Project Dataset User's Manual"
} 
mate/winner or loser"). The "winner or loser" variable only includes ceasefires that followed wars that ended with a decisive victory for one side. For this variable, the winner is coded as 1 and the loser as 0.

\section{EMPIRICAL FINDINGS}

\section{BASELINE PROSPECTS FOR VIOLATION OF CEASEFIRE AGREEMENTS}

Since the dependent variable is binary, a logistic regression model is used to estimate the effect of each independent variable on state behavior (i.e., the violation of ceasefire agreements). Table 2 shows the results of the logistic regressions that examine Hypotheses (a) to (e) at once. The table reports the coefficients and robust standard errors from the logistic regressions. To test Hypotheses (a) and (a-1), Model 1 and Model 2 are distinguished. Model 1 only examines disputes resumed between democratic and nondemocratic states to determine whether differences in regime type affect the violation of ceasefire agreements, while Model 2 examines all cases, including disputes among nondemocracies. ${ }^{6}$

Model 1 shows that regime type is irrelevant to state behavior; that is, a democratic state is no different from a nondemocratic state in terms of commitment to ceasefire agreements. Thus, Hypothesis (a) seems to be rejected. Otherwise, it appears that the relative capabilities variable has a statistically significant effect on the dependent variable. As shown in Table 2, a state with a favorable position in relative capabilities is more likely to resume military conflict than its weaker counterpart. More specifically, observing the marginal changes in the table, we can see that when the relative capabilities variable changes from a half standard deviation below the mean to a half standard deviation above the mean, the probability that a state will break a ceasefire increases by 9.65 percentage points.

Model 2 makes the results more robust. While Model 1 only examines disputes between democratic and nondemocratic states, Model 2 assesses all cases in which a ceasefire agreement was violated. Here, the order type variable is used to assess the effect of differences in the level of democracy on the violation of cease-

\footnotetext{
${ }^{6}$ For the cases of the Agreement between the Government of the State of Eritrea and the Government of the Federal Democratic Republic of Ethiopia (2000), which is not included in the data used in this paper but included in the UCDP dataset, there are six cases of violations of the agreement between 2000 and 2007, according to the MID data. These cases should be included in Model 2 because Ethiopia and Eritrea are both considered nondemocracies based on the Polity IV data. Although the data used in this paper should be updated by adding these cases, it is expected to have a limited impact on the number of observations for the model.
} 
Table 2. Coefficients and Robust Standard Errors from Logistic Regression Models: Determinants of Violation

\begin{tabular}{|c|c|c|c|c|}
\hline \multirow{2}{*}{$\begin{array}{c}\text { Dependent Variable } \\
\operatorname{Pr}(\text { Violator }=1)\end{array}$} & \multicolumn{2}{|c|}{ Model 1} & \multicolumn{2}{|c|}{ Model 2} \\
\hline & $\begin{array}{c}\text { Coefficient } \\
\text { (SE) }\end{array}$ & $\begin{array}{l}\text { Marginal } \\
\text { Changes }\end{array}$ & $\begin{array}{l}\text { Coefficient } \\
\text { (SE) }\end{array}$ & $\begin{array}{l}\text { Marginal } \\
\text { Changes }\end{array}$ \\
\hline Regime Type & $\begin{array}{l}-0.0523 \\
(0.3180)\end{array}$ & -0.0065 & & \\
\hline Level of Democracy & & & $\begin{array}{l}-.0164 \\
(.0134)\end{array}$ & -0.0399 \\
\hline Relative Capabilities & $\begin{array}{c}1.5191^{* * *} \\
(0.5220)\end{array}$ & 0.0965 & $\begin{array}{c}1.0108^{* * *} \\
(.3401)\end{array}$ & 0.0968 \\
\hline $\begin{array}{c}\text { Change in Relative } \\
\text { Capabilities }\end{array}$ & $\begin{array}{l}-0.2364^{*} \\
(0.1423)\end{array}$ & -0.0491 & $\begin{array}{l}.0169^{* \star *} \\
(.0062)\end{array}$ & 0.0420 \\
\hline Cost of War & $\begin{array}{l}-0.0510 \\
(0.0837)\end{array}$ & -0.0284 & $\begin{array}{l}-.1417 \\
(.2617)\end{array}$ & 0.0001 \\
\hline $\begin{array}{l}\text { Winner/Loser or } \\
\text { Stalemate }\end{array}$ & $\begin{array}{c}-0.9173^{* *} \\
(0.3543)\end{array}$ & -0.1095 & $\begin{array}{l}.2533 \\
(.2929)\end{array}$ & -0.0170 \\
\hline $\begin{array}{c}\text { Stalemate/ } \\
\text { Winner or Loser }\end{array}$ & $\begin{array}{l}-0.1822 \\
(0.4501)\end{array}$ & -0.0207 & $\begin{array}{c}.0197 \\
(.0576)\end{array}$ & -0.0257 \\
\hline Constant & $\begin{array}{c}0.3559 \\
(0.7375)\end{array}$ & & $\begin{array}{l}-.6531 \\
(.5021)\end{array}$ & \\
\hline $\mathrm{N}$ & 310 & & 488 & \\
\hline $\begin{array}{c}\text { Log Likelihood } \\
\text { Chi }^{2} \\
\text { Pseudo } \mathrm{R}^{2}\end{array}$ & $\begin{array}{c}-202.504 \\
0.0006 \\
0.0576\end{array}$ & & $\begin{array}{c}-331.5163 \\
0.0063 \\
0.0196\end{array}$ & \\
\hline
\end{tabular}

Note: The marginal change is a change in the predicted probability of observing $y=1$ as each continuous independent variable changes from 1/2 SD below the mean to $1 / 2 \mathrm{SD}$ above the mean, with all variables at their mean. The marginal change for dummy variable is a change in the predicted probability as the dummy changes from 0 to 1 , with other variables constant at their mean. ${ }^{*} p<.10,{ }^{* *} p<.05,{ }^{* *} p<.01$ (two-tailed tests)

fire agreements. Although it examines a larger number of cases and a different type of variable, the results appear nearly the same: the effect of regime type difference or level of democracy is not statistically significant. This implies that democratic advantages, which are generally expected to help democracies commit themselves to agreements, are not effective, at least not in this respect. Otherwise, relative capabilities have a statistically significant effect on ceasefire agreement violation. As with Model 1, Model 2 indicates that a state with superior capabilities is more likely to violate a ceasefire agreement. From both Model 1 and 2, Hypothesis (b) cannot be rejected here.

Model 2 also shows that "change in relative capabilities," which shows how relative capabilities changed from when a ceasefire agreement was signed to when it was violated, also affects state behavior in terms of violating ceasefire agree- 
ments. Model 2 indicates that if relative capabilities change favorably for a state then that state is more likely to violate an agreement and attempt to resume military conflict. More specifically, the marginal change in Table 2 shows that when the variable "change in relative capabilities" moves from a half standard deviation below the mean to a half standard deviation above the mean, the probability that a state will violate a ceasefire agreement increases by 4.2 percentage points. This result contradicts the logic of preventive war, which means that Hypothesis (c) seems not to be rejected while Hypothesis (c-1) seems to be rejected. However, in Model 1, despite its limited statistical significance $(\mathrm{p}<0.1)$, change in relative capabilities has an effect on violation in the opposite direction. Model 1 shows that a rising power is less likely to pursue military action than its counterpart. In other words, a declining power is more likely to take military action than a rising power, in violation of the ceasefire agreement. In contrast with Model 2, this supports Hypothesis (c-1) rather than Hypothesis (c).Since Models 1 and 2 report different results regarding the effect of power shifts on the commitment to ceasefire agreements, the implications of the results are problematic. It is possible that the results are distorted or that Models 1 and 2 are systematically different in this respect. However, with only these results, it is not possible to identify the general effect of power shifts on commitment.

In summary, based on Table 2, Hypothesis (a) that democracies are more likely to respect agreements should be rejected, at least with regard to ceasefire agreements. Hypothesis (a-1) that more democratic states are more likely to respect ceasefire agreements should also be rejected. Rather, it seems that relative capabilities and changes in relative capabilities have statistically significant effects on a state ${ }^{\circ} Ø$ s decisions to violate agreements, while Models 1 and 2 report conflicting results regarding the effect of power shifts.

\section{DOES THE ARAB-ISRAELI EFFECT EXIST?}

Based on Table 2, regime type and level of democracy do not seem to affect the violation of ceasefire agreements. However, some might question whether the effect of regime type could appear insignificant because of the Arab-Israeli conflict. Since 1948, Israel has been a strong democracy, according to Polity IV data. In addition, it is well known that given the repeated conflicts in the Middle East, Israel, a strong democratic state, has initiated many military actions, despite ceasefire agreements. Thus, excluding the ongoing Arab-Israeli conflict, regime type and level of democracy might appear as significant. However, Table 3 shows that this is not the case. 
Table 3. Coefficients and Robust Standard Errors from Logistic Regression Models: Determinants of Violation (excluding the Arab-Israeli conflict)

\begin{tabular}{|c|c|c|c|c|}
\hline \multirow{2}{*}{$\begin{array}{c}\text { Dependent Variable } \\
\operatorname{Pr}(\text { Violator=1) }\end{array}$} & \multicolumn{2}{|c|}{ Model 1-1 } & \multicolumn{2}{|c|}{ Model 2-1 } \\
\hline & $\begin{array}{l}\text { Coefficient } \\
\text { (SE) }\end{array}$ & $\begin{array}{l}\text { Marginal } \\
\text { Changes }\end{array}$ & $\begin{array}{l}\text { Coefficient } \\
\text { (SE) }\end{array}$ & $\begin{array}{l}\text { Marginal } \\
\text { Changes }\end{array}$ \\
\hline Regime Type & $\begin{array}{l}-0.8529 \\
(0.5559)\end{array}$ & -0.1066 & & \\
\hline Level of Democracy & & & $\begin{array}{l}-0.0057 \\
(0.0167)\end{array}$ & -0.0112 \\
\hline Relative Capabilities & $\begin{array}{c}1.0992 \\
(1.1499)\end{array}$ & 0.0836 & $\begin{array}{l}0.8488^{* *} \\
(0.4300)\end{array}$ & 0.0657 \\
\hline $\begin{array}{c}\text { Change in Relative } \\
\text { Capabilities }\end{array}$ & $\begin{array}{c}-0.4733^{\star * *} \\
(0.1719)\end{array}$ & -0.1424 & $\begin{array}{c}-0.2870^{* *} \\
(0.1225)\end{array}$ & -0.0565 \\
\hline Cost of War & $\begin{array}{l}-0.4111 \\
(0.2596)\end{array}$ & -0.2568 & $\begin{array}{c}0.0965 \\
(0.0732)\end{array}$ & 0.0584 \\
\hline $\begin{array}{l}\text { Winner/Loser or } \\
\text { Stalemate }\end{array}$ & $\begin{array}{l}-1.2127 \\
(0.9162)\end{array}$ & -0.1196 & $\begin{array}{c}0.6397 \\
(0.3790)\end{array}$ & 0.0623 \\
\hline $\begin{array}{c}\text { Stalemate/ } \\
\text { Winner or Loser }\end{array}$ & $\begin{array}{c}1.5499 \\
(1.2235)\end{array}$ & 0.1872 & $\begin{array}{l}-0.0238 \\
(0.3538)\end{array}$ & -0.0030 \\
\hline Constant & $\begin{array}{c}3.9552 \\
(2.4524)\end{array}$ & & $\begin{array}{l}-1.2447^{*} \\
(0.6854)\end{array}$ & \\
\hline $\mathrm{N}$ & 124 & & 322 & \\
\hline $\begin{array}{c}\text { Log Likelihood } \\
C h i^{2} \\
\text { Pseudo } R^{2}\end{array}$ & $\begin{array}{c}-79.2702 \\
0.0024 \\
0.0777\end{array}$ & & $\begin{array}{c}-214.8997 \\
0.0071 \\
0.0333\end{array}$ & \\
\hline
\end{tabular}

Note: The marginal change is the change in the predicted probability of observing $y=1$ as each continuous independent variable changes from $1 / 2$ SD below the mean to $1 / 2 \mathrm{SD}$ above the mean, with all variables at their mean. The marginal change for dummy variable is the change in the predicted probability as the dummy changes from 0 to 1 , with other variables constant at their means. ${ }^{*} p<.10,{ }^{* *} p<.05,{ }^{* * *} p<.01$ (two-tailed tests)

Model 1-1 in Table 3 examines cases in which democracies fight nondemocracies, excluding Arab-Israeli conflicts. It shows that, even without the Arab-Israeli cases, regime type still does not affect the tendency to violate agreements. Model 2-1 assesses all cases in which ceasefire agreements were broken, excluding ArabIsraeli cases, and also indicates that the level of democracy is irrelevant with regard to violations. Thus, even excluding Arab-Israeli cases, Hypotheses (a) and(a-1) should be rejected.

Although the results shown in Table 3 are not perfectly consistent with those of Table 2, Model 2-1 shows that "relative capabilities" works in the same manner as Models 1 and 2 from Table 2. Although its statistical significance is limited, relative capabilities in Model 1-1 also has effects in the same direction. According to these findings, Hypothesis (b) (i.e., a state with superior capabilities is more like- 
ly to violate ceasefire agreements) should not be rejected.

Models 1-1 and 2-1 both indicate that changes in relative capabilities have statistically significant effects on the violation of agreements. A rising state in terms of relative capabilities is less likely to violate agreements, while a declining one is more likely to resume conflict. Unlike Models 1 and 2, Models 1-1 and 2-1 show that the variable "change in relative capabilities" works in the same direction. Here, Hypothesis (c-1) seems not to be rejected by both results, while Hypothesis (c) seems to be rejected. These results strengthen the argument that a declining power is more likely to resume conflict for preventive purposes.

Overall, Models 1-1 and 2-1 show that the lack of effect of regime type and level of democracy on violation behavior is not attributable to the uniqueness of the Arab-Israeli conflict. Excluding Arab-Israeli conflicts from the data, regime type and level of democracy do not have significant effects on the violation of ceasefire agreements. Despite controlling for the Arab-Israeli cases, democracies are not different from nondemocracies in terms of commitment to ceasefire agreements, while relative capabilities appears to be statistically significant in Model 2-1. In addition, Models 1-1 and 2-1 indicate that a change in relative capabilities has a statistically significant effect on commitment to ceasefire agreements in the same direction: as a state's relative capabilities decreases, it is less likely to commit to agreements.

\section{OUTCOME OF THE WAR AND THE VIOLATION OF CEASEFIRE AGREEMENTS}

Previous studies examine the effect of war outcomes on the durability of peace or stability after a ceasefire. They argue that the rate of conflict recurrence differs between wars that end in a stalemate and those that end with a decisive victory/defeat; specifically, the likelihood of conflict recurrence is higher when a previous war ended in a stalemate7 (Maoz 1984; Hensel 1999; Stinnett and Diehl 2001). Following this argument, we may ask whether the determinants affecting a state's commitment to agreements are the same despite different war outcomes. In order to address this question, cases were categorized depending on the outcome of war - whether the war ended with a decisive victory for one side or just ended in stalemate. The effect of each independent variable on the dependent variable is explored separately in each category.

Table 4 shows the results of logistic regression for cases of violations of cease-

\footnotetext{
7 There are different perspectives on the effect of war outcome on recurrent conflict. To review these perspectives, see Quackenbush and Venteicher (2008). The authors argue that war outcome only has an indirect effect on the rate of conflict recurrence rather than a direct and dominant effect.
} 
Table 4.Coefficients and Robust Standard Errors from Logistic Regression Model: Determinants of Violation: War Followed by Ceasefire Agreement that Ended in Decisive Victory or Defeat

\begin{tabular}{|c|c|c|c|c|}
\hline \multirow{2}{*}{$\begin{array}{c}\text { Dependent Variable } \\
\operatorname{Pr}(\text { Violator }=1)\end{array}$} & \multicolumn{2}{|c|}{ Model 3} & \multicolumn{2}{|c|}{ Model 4} \\
\hline & $\begin{array}{l}\text { Coefficient } \\
\text { (SE) }\end{array}$ & $\begin{array}{l}\text { Marginal } \\
\text { Changes }\end{array}$ & $\begin{array}{l}\text { Coefficient } \\
\text { (SE) }\end{array}$ & $\begin{array}{l}\text { Marginal } \\
\text { Changes }\end{array}$ \\
\hline Regime Type & $\begin{array}{c}0.4404 \\
(0.4313)\end{array}$ & 0.1097 & & \\
\hline Level of Democracy & & & $\begin{array}{c}0.0255 \\
(0.0198)\end{array}$ & -0.0500 \\
\hline Relative Capabilities & $\begin{array}{c}2.1110^{* * *} \\
(0.6550)\end{array}$ & 0.1260 & $\begin{array}{l}1.0759 * * \\
(0.4598)\end{array}$ & 0.0720 \\
\hline $\begin{array}{c}\text { Change in Relative } \\
\text { Capabilities }\end{array}$ & $\begin{array}{c}0.2828 \\
(0.6330)\end{array}$ & 0.0239 & $\begin{array}{c}0.3563 \\
(0.5646)\end{array}$ & 0.7799 \\
\hline Cost of War & $\begin{array}{l}-0.1825 \\
(0.1505)\end{array}$ & -0.0498 & $\begin{array}{l}-0.1387 \\
(0.1138)\end{array}$ & 0.0409 \\
\hline Win or Lose & $\begin{array}{l}-1.1768^{* *} \\
(0.4661)\end{array}$ & -0.2860 & $\begin{array}{l}-0.0528 \\
(0.3139)\end{array}$ & 0.0131 \\
\hline Constant & $\begin{array}{c}0.3592 \\
(1.4520)\end{array}$ & & $\begin{array}{c}0.1793 \\
(1.1640)\end{array}$ & \\
\hline $\mathrm{N}$ & 220 & & 300 & \\
\hline $\begin{array}{c}\text { Log Likelihood } \\
C h i^{2} \\
\text { Pseudo } R^{2}\end{array}$ & $\begin{array}{c}-141.468 \\
0.0034 \\
0.0723\end{array}$ & & $\begin{array}{c}-201.140 \\
0.0503 \\
0.0326\end{array}$ & \\
\hline
\end{tabular}

Note: The marginal change is the change in the predicted probability of observing $y=1$ as each continuous independent variable changes from 1/2 SD below the mean to $1 / 2 \mathrm{SD}$ above the mean, with all variables at their means. ${ }^{*} p<.10,{ }^{* *} p<.05,{ }^{* * *} p<.01$ (two-tailed tests)

fire agreements where previous wars ended in a decisive victory/defeat. It is consistently shown that democracies are no different from nondemocracies with regard to commitment to agreements. Again, Hypotheses (a) and (a-1) are both rejected. As in Tables2 and 3, Table 4 affirms that differences in regime type and level of democracy have no effect on state behavior in this regard, while relative capabilities has a significant effect on the dependent variable. Models 3 and 4 both report that states with relatively superior capabilities are more likely to resume military conflict in violation of agreements. Marginal changes in the table show that when relative capabilities changes from a half standard deviation below the mean to a half standard deviation above the mean, the probability that a state will violate an agreement increases by 12.6 and 7.2 percentage points in Models 3 and 4 , respectively.

What is interesting here is that, while relative capabilities affect state behavior, the effect of the variable "change in relative capabilities" appears statistically 
insignificant in Table 4, unlike in Tables2 and 3. Compared with the results reported in Table 5, this becomes much more conspicuous.

Table 5. Coefficients and Robust Standard Errors from Logistic Regression Models: Determinants of Violation: War Followed by Ceasefire Agreement that Ended in Stalemate

\begin{tabular}{|c|c|c|c|c|}
\hline \multirow{2}{*}{$\begin{array}{c}\text { Dependent Variable } \\
\text { Pr(Violator=1) }\end{array}$} & \multicolumn{2}{|c|}{ Model 5} & \multicolumn{2}{|c|}{ Model 6} \\
\hline & $\begin{array}{l}\text { Coefficient } \\
\text { (SE) }\end{array}$ & $\begin{array}{l}\text { Marginal } \\
\text { Changes }\end{array}$ & $\begin{array}{l}\text { Coefficient } \\
\text { (SE) }\end{array}$ & $\begin{array}{l}\text { Marginal } \\
\text { Changes }\end{array}$ \\
\hline Regime Type & $\begin{array}{l}-0.2037 \\
(0.5439)\end{array}$ & -0.0507 & & \\
\hline Level of Democracy & & & $\begin{array}{l}-0.0016 \\
(0.0225)\end{array}$ & -0.0033 \\
\hline Relative Capabilities & $\begin{array}{c}0.3270 \\
(1.0725)\end{array}$ & 0.0236 & $\begin{array}{c}0.7041 \\
(0.6657)\end{array}$ & 0.0498 \\
\hline $\begin{array}{l}\text { Change in Relative } \\
\text { Capabilities }\end{array}$ & $\begin{array}{c}-0.6902^{* * *} \\
(0.2252)\end{array}$ & -0.2355 & $\begin{array}{c}-0.3648^{* * *} \\
(0.1360)\end{array}$ & -0.0916 \\
\hline Cost of War & $\begin{array}{c}0.0382 \\
(0.1123)\end{array}$ & 0.0202 & $\begin{array}{l}0.1278^{*} \\
(0.0721)\end{array}$ & 0.0732 \\
\hline Constant & $\begin{array}{c}0.4761 \\
(1.4412)\end{array}$ & & $\begin{array}{l}-1.3961 \\
(0.9252)\end{array}$ & \\
\hline $\mathrm{N}$ & 90 & & 188 & \\
\hline $\begin{array}{l}\text { Log Likelihood } \\
\text { Chi } \\
\text { Pseudo } R^{2}\end{array}$ & $\begin{array}{l}-57.468 \\
0.0061 \\
0.0785\end{array}$ & & $\begin{array}{l}-125.737 \\
0.0070 \\
0.0344\end{array}$ & \\
\hline
\end{tabular}

Note: The marginal change is the change in the predicted probability of observing $y=1$ as each continuous independent variable changes from 1/2 SD below the mean to 1/2 SD above the mean, with all variables at their means. ${ }^{*} p<.10,{ }^{* *} p<.05,{ }^{* * *} p<.01$ (two-tailed tests)

Table 5 shows the results of logistic regression for cases in which ceasefire agreements were violated when previous wars ended in stalemate. Like Tables 2, 3 , and 4 , Table 5 shows that regime type and level of democracy do not have a significant effect on the dependent variable. However, the results differ from those reported in Table 4 with regard to the capabilities variable. Unlike Table 4 , Table 5 reports that a change in relative capabilities has a statistically significant effect on the dependent variable, while relative capabilities itself does not have an effect on it. According to Models 5 and 6, a state that has experienced a relative reduction in capabilities since a ceasefire was signed is more likely to resume conflict, as Models 1, 1-1, and 2-1 show. These findings differ from those of Models 3 and 4 in Table 4 . While Models 3 and 4 show that relative power in a static state has a statistically significant effect on violation of the agreement, Models 5 and 6 indicate that relative power in a dynamic situation affects violation. This inconsistency between the models implies that, depending on the outcome of a war, the 
contributing factors that affect violation may differ.

With only the results reported here, it is difficult to explain why this discrepancy exists; however, several hypotheses can be suggested. Following previous studies reporting that the likelihood of conflict recurrence varies depending on war outcome, conflicts are more likely to recur when previous wars ended in stalemate rather than ended with decisive victory. Accordingly, states that experienced a war ending in stalemate are more likely to be concerned about the possibility of being attacked. Thus, those states may be more likely to take preventive action - as Models 5 and 6 suggest - out of fear that their adversary will strike them again. Otherwise, there is the possibility that when a war ends in stalemate, the gap between the capabilities of the two parties may be much narrower than in cases where a war ends in a decisive victory for one side. If this is the case, a state that experiences a war ending in stalemate might be more sensitive to changes in relative capabilities. 8

However, the possible explanations suggested here are not thoroughly scrutinized and more research is needed to develop valid explanations for the results in Tables 4 and 5 .

\section{CONCLUSION}

Who beats plowshares into swords despite the existence of a ceasefire agreement? Under what circumstances are states more likely to renege on their commitment to such agreements? This paper explores these questions and seeks to find the determinants of a state's commitment to agreements by empirical testing.

Four conclusions emerge from the results. First, regime type and level of democracy do not have statistically significant effects on a state's propensity to violate ceasefire agreements Thus, Hypotheses (a) and (a-1) were rejected. All empirical results reported in this paper show that democratic commitment does not affect ceasefire agreement violation. The same hypotheses were tested excluding Arab-Israeli conflicts, and the results still showed that democracies were no different from nondemocracies with regard to violation of ceasefire agreements. At least against old enemies, democratic states were no less likely than nondemocratic states to violate agreements and resume military conflicts. This result is conspicuous because it raises questions about whether democratic institutions are effective in restraining the behavior of states and making them more reliable agreement partners. It suggests that democracies might remain

\footnotetext{
${ }^{8}$ The authors would like to thank an anonymous reviewer for this criticism.
} 
committed only selectively, not generally, at least with respect to their nondemocratic adversaries. Additionally, although the discussion here is limited to the violation of ceasefire agreements, it is possible to draw a conclusion that democracies are proactive in taking countermeasures, especially with regard to security issues.

Second, a state with greater relative capabilities than its enemy was more likely to resume military conflict; thus, Hypothesis (b) could not be rejected. Although the significance of the effect of relative capabilities differs depending on the outcome of war, Tables 2, 3 and 4 show that the larger the power gap, the less likely the superior state is to commit to the ceasefire agreement.

Third, according to Models 1, 1-1, 2-1, 5, and 6, states that have experienced growth in relative capabilities since the ceasefire were less likely to violate agreements; thus, Hypothesis (c) seemed to be rejected while Hypothesis (c-1) appeared not to be rejected. With these empirical findings, we can suggest that power shifts may make international commitments more unreliable. Moreover, this finding supported the logic of preventive war because states experiencing a reduction in relative capabilities since the ceasefire were more likely to resume conflict than states experiencing growth in capabilities relative to their adversaries.

Fourth, the effects of relative power and power shifts differ depending on the outcome of war. When states experienced a decisive victory or defeat in the previous war, their behavior was affected by relative power, while a power shift did not have a statistically significant effect. On the other hand, when states experienced a war ending in stalemate, power shifts had an effect on their behavior while relative power did not. These finding imply that the variables affecting commitment may differ depending on a state's previous war experiences.

Despite these findings, this paper leaves a few research questions unaddressed. First, the data used in this paper should be updated, with more recent cases added. In addition, in order to further develop the discussion, the results should be tested to see whether they still hold when the data cover all sorts of peace agreements signed between two opposing parties. Since this paper only considers ceasefires followed by interstate wars that result in more than 1,00o battlerelated deaths, it is questionable whether the results would be consistent with cases where agreements were signed after other kinds of armed conflict.

Second, this paper lacks the insights that might be gleaned from case studies, which could provide more rich and detailed information about the determinants of state behavior. Analyzing cases that show variation in the independent variables will improve our understanding of the mechanisms by which states are affected by the determinants of violation. Since this paper tested hypotheses 
using a large sample only, research that included case studies should be pursued.

Finally, the implications of the empirical findings of this paper should be discussed more thoroughly. Hypotheses (a) and (a-1) were rejected in all models. This implies that regime type and level of democracy do not have a significant effect on a state's commitment to an agreement. Thus, we might question why democratic institutions appear to be ineffective in this regard. Examining this question could contribute to further understanding of the commitment mechanism. In addition, the results reported in Tables 4 and 5 show that the determinants of violation of an agreement differ depending on the outcome of previous wars. This suggests that a state's commitment mechanisms may differ depending on the outcomes of wars. However, this raises a question about why this difference exists. Why do the determinants of commitment vary depending on the outcome of war? This paper provides a possible explanation that states experiencing a war ending in stalemate are more likely to be concerned about power shifts since the likelihood of conflict recurrence is expected to be higher than in cases of wars involving decisive victory/defeat. Moreover, the gap in relative capabilities between two opposing parties might differ depending on the outcome of war, so there exists a discrepancy between states experienced wars ending in stalemate and states experiencing wars ending with a decisive outcome. However, since these possible explanations are not thoroughly scrutinized, further research is needed.

This paper does not contribute to our understanding of what are the favorable conditions for durable peace following a ceasefire. Instead, it focuses only on ceasefires that collapse. By focusing on such cases, it points out that there are variations in the behaviors of states regarding their commitment to ceasefire agreements. Moreover, this paper explores what causes these variations and under what conditions states beat plowshares back into swords despite ceasefire agreements.

\section{REFERENCES}

Bennett, D. Scott. 1998. "Integrating and Testing the Models of Rivalry Duration." American Journal of Political Science 42(4), 1200-1232.

Fortna, Virginia Page. 2004. Peace Time: Cease-Fire Agreements and the Durability of Peace. Princeton, NJ: Princeton University Press.

Gartzke, Erik and Kristian Skrede Gleditsch. 2004. "Why Democracies May Actually Be Less Reliable Allies." American Journal of Political Science 48(4), 775-795. 
Gaubatz, Kurt Taylor. 1996. "Democratic States and Commitment in International Relations.” International Organization 50(1), 109-139.

Goertz, Gary, and Paul F. Diehl. 1993. "Enduring Rivalries: Theoretical Constructs and Empirical Patterns." International Studies Quarterly 37(2),147-171.

Grieco, Joseph M. 2001. "Repetitive Military Challenges and Recurrent International Conflicts, 1918-1994." International Studies Quarterly 45(2), 295-316.

Hensel, Paul R. "An Evolutionary Approach to the Study of Interstate Rivalry." Conflict Management and Peace Science 17(2),175-206.

Leeds, Brett Ashely, Michaela Mattes, and Jeremy S. Vogel. 2009. "Interest, Institutions, and the Reliability of International Commitment." American Journal of Political Science 53(2), 461-476.

Maoz, Zeev. 1984. "Peace by Empire? Conflict Outcomes and International Stability, 1816-1976.” Journal of Peace Research 21(3), 227-241.

Martin, Lisa L. 2000. Democratic Commitments: Legislatures and International Cooperation. Princeton, NJ: Princeton University Press.

McGillivray, Fiona and Alastair Smith. 2008. Punishing the Prince: A Theory of Interstate Relations, Political Institutions, and Leader Change. Princeton, NJ: Princeton University Press.

Powell, Robert. 2012. "Persistent Fighting and Shifting Power." American Journal of Political Science 56(3), 620-637.

Quackenbush, Stephen L. and Jerome F. Venteicher. 2008. "Settlements, Outcomes, and the Recurrence of Conflict." Journal of Peace Research 45(6), 723-742.

Simmons, Beth A. 2000. "International Law and State Behavior: Commitment and Compliance in International Monetary Affairs." American Political Science Review 94(4), 819-835.

Stinnett, Douglas M., and Paul F. Diehl. 2001. "The Path to Rivalry: Behavioral and Structural Explanations of Rivalry Development." Journal of Politics 63(3), 717-740.

Van Evera, Stephen. 1999. Causes of War: Power and the Roots of Conflict. Ithaca, NY: Cornell University Press.

Werner, Suzanne. 1999. "The Precarious Nature of Peace: Resolving the Issues, Enforcing the Settlement and Renegotiating the Terms." American Journal of Political Science 43(3), 912-934. 
Appendix 1. Descriptions of Some Key Variables Used in the Analysis

\begin{tabular}{|c|c|c|c|c|c|}
\hline Variable & Value & Source & Mean & SD & $\mathbf{N}$ \\
\hline Regime Type & $\begin{array}{c}0=\text { nondemocracy } \\
1=\text { democracy }\end{array}$ & Polity IV & .4279 & .4952 & 523 \\
\hline $\begin{array}{c}\text { Level of } \\
\text { Democracy }\end{array}$ & =Polity IV score & Polity IV & .3792 & 8.1058 & 523 \\
\hline $\begin{array}{l}\text { Relative } \\
\text { Capability }\end{array}$ & $\begin{array}{c}=\text { CINC score of state_1/CINC } \\
\text { score of state_2 }\end{array}$ & NMC “CINC" & .5066 & .2848 & 545 \\
\hline $\begin{array}{l}\text { Change in } \\
\text { Relative } \\
\text { Capability }\end{array}$ & $\begin{array}{c}=\text { rel. cap in the time of } \\
\text { violation/rel. cap in the } \\
\text { time of war }\end{array}$ & NMC “CINC" & 1.5029 & 8.3369 & 545 \\
\hline Cost of War & $\begin{array}{l}=\text { natural log of state's battle } \\
\text { deaths }\end{array}$ & Cow "batdeath" & 8.9726 & 2.3857 & 543 \\
\hline $\begin{array}{l}\text { Winner/Loser } \\
\text { or Stalemate }\end{array}$ & $\begin{array}{c}0=\text { loser or stalemate } \\
1=\text { winner }\end{array}$ & MIDB “outcome" & .2855 & .4520 & 522 \\
\hline $\begin{array}{c}\text { Stalemate/ } \\
\text { Winner or Loser }\end{array}$ & $\begin{array}{c}0=\text { stalemate } \\
1=\text { winner or loser }\end{array}$ & MIDB “outcome" & .4290 & .4953 & 522 \\
\hline
\end{tabular}

Appendix 2. List of Ceasefires between 1946 and 1997

\begin{tabular}{c|c|c|c|c}
\hline War & Ceasefire & $\begin{array}{c}\text { Violation } \\
\text { (date of the first } \\
\text { violation) }\end{array}$ & \multicolumn{2}{|c}{ Between } \\
\hline Palestine 1 & 18 July 1948 & 15 Oct 1948 & Israel & Iraq \\
\hline Palestine 1 & 18 July 1948 & 15 Oct 1948 & Israel & Egypt \\
\hline Palestine 1 & 18 July 1948 & 15 Oct 1948 & Israel & Syria \\
\hline Palestine 1 & 18 July 1948 & 15 Oct 1948 & Israel & Lebanon \\
\hline Palestine 1 & 18 July 1948 & 15 Oct 1948 & Israel & Jordan \\
\hline Palestine 2 & 7 Jan 1949 & 23 Dec 1949 & Israel & Egypt \\
\hline Palestine 2 & 31 Oct 1948 & 6 April 1949 & Israel & Syria \\
\hline Palestine 2 & 31 Oct 1948 & 7 Jan 1949 & Israel & Jordan \\
\hline Palestine 2 & 31 Oct 1948 & 11 Jan 1959 & Israel & Lebanon \\
\hline Palestine 2 & 31 Oct 1948 & 16 Dec 1966 & Israel & Iraq \\
\hline First Kashmir & 1 Jan 1949 & 14 April 1949 & Pakistan & India \\
\hline Korean & 29 July 1953 & 2 Sept 1953 & US & China \\
\hline Korean & 29 July 1953 & 13 Jan 1954 & US & No. Korea \\
\hline Korean & 29 July 1953 & 25 Dec 1955 & So. Korea & China \\
\hline Korean & 29 July 1953 & 13 Jan 1954 & So. Korea & No. Korea \\
\hline 14 Nov 1956 & N Nov 1956 & 14 May 1958 & UK & Egypt \\
\hline
\end{tabular}


The Korean J ournal of I nternational Studies 13- 3 | 512

\begin{tabular}{|c|c|c|c|c|}
\hline War & Ceasefire & $\begin{array}{c}\text { Violation } \\
\text { (date of the first }\end{array}$ & \multicolumn{2}{|c|}{ Between } \\
\hline Sinai & $\mathrm{N} / \mathrm{A}$ & $\mathrm{N} / \mathrm{A}$ & France & Egypt \\
\hline Sinai & 3 April 1957 & 3 April 1957 & Israel & Egypt \\
\hline Sino-Indian & 1 Dec 1962 & 1 Dec 1962 & China & India \\
\hline Vietnamese & $\mathrm{N} / \mathrm{A}$ & $\mathrm{N} / \mathrm{A}$ & No. Vietnam & US \\
\hline Vietnamese (censored immediately) & $\mathrm{N} / \mathrm{A}$ & $\mathrm{N} / \mathrm{A}$ & No. Vietnam & So. Vietnam \\
\hline Second Kashmir & Aug 1964 & Aug 1964 & Pakistan & India \\
\hline Six Day & 26 June 1967 & 26 June 1967 & Egypt & Israel \\
\hline Six Day & 15 June 1967 & 15 June 1967 & Syria & Israel \\
\hline Six Day & 15 July 1967 & 15 July 1967 & Jordan & Israel \\
\hline Israeli-Egyptian & 7 Aug 1970 & 18 Oct 1970 & Israel & Egypt \\
\hline Football & 18 July 1969 & 13 July 1976 & Honduras & El Salvador \\
\hline Bangladesh & 17 Dec 1971 & 5 May 1972 & India & Pakistan \\
\hline Yom Kippur & 24 Oct 1973 & 4 May 1990 & Israel & Jordan \\
\hline Yom Kippur & 24 Oct 1973 & 7 Nov 1973 & Israel & Syria \\
\hline Yom Kippur & 24 Oct 1973 & 14 Nov 1977 & Israel & Egypt \\
\hline Turco-Cypriot 1 & 29 July 1974 & 16 Aug 1974 & Turkey & Cyprus \\
\hline Turco-Cypriot 2 & 16 Aug 1974 & 28 May 1988 & Turkey & Cyprus \\
\hline Ethiopian-Somalian & 14 March 1978 & N/A & Somalia & Cuba \\
\hline Ethiopian-Somalian & 14 March 1978 & 14 April 1978 & Ethiopia & Somalia \\
\hline Ugandan-Tanzanian & 12 April 1979 & N/A & Uganda & Tanzania \\
\hline Ugandan-Tanzanian & 12 April 1979 & N/A & Libya & Tanzania \\
\hline Sino-Vietnamese & 10 March 1979 & 5 May 1981 & China & Vietnam \\
\hline Iran-Iraq & 20 Aug 1988 & 17 Feb 1989 & Iran & Iraq \\
\hline Falklands & 20 June 1982 & 12 Aug 1982 & UK & Argentina \\
\hline Lebanon & 5 Sept 1982 & 4 Oct 1982 & Israel & Syria \\
\hline Sino-Vietnamese & 6 Feb 1987 & 5 Oct 1987 & China & Vietnam \\
\hline Gulf War & 11 April 1991 & 27 July 1992 & US & Iraq \\
\hline Gulf War & 11 April 1991 & $\mathrm{~N} / \mathrm{A}$ & Saudi Arabia & Iraq \\
\hline Gulf War & 11 April 1991 & 7 Aug 1991 & Kuwait & Iraq \\
\hline Azeri-Armenian 1 & 21 Mar 1992 & 8 March 1995 & Armenia & Azerbaijan \\
\hline Azeri-Armenian 2 & 12 May 1994 & $\mathrm{~N} / \mathrm{A}$ & Armenia & Azerbaijan \\
\hline
\end{tabular}

